\title{
Volatility Spillover Effect of International Crude Oil Futures and China-Russia Stock Market: A Multivariate BEKK-GARCH Model Based on Wavelet Multiresolution Analysis
}

Maoguo Wu (Corresponding author)

Maoguo Wu, SHU-UTS SILC Business School, Shanghai University, Shanghai, China

Daimin Lu

SHU-UTS SILC Business School, Shanghai University, Shanghai, China

Received: Feb. 15, 2019 Accepted: May 17, $2019 \quad$ Published: June 1, 2019

doi:10.5296/ajfa.v11i1.14348 URL: https://doi.org/10.5296/ajfa.v11i1.14348

\begin{abstract}
The increasingly prominent strategic position of crude oil determines its high impact on macro-economy. The value of crude oil is reflected in the price of crude oil futures. Stock market is the barometer of macro economy. To what extent does international crude oil futures price affect stock market? China and Russia are the biggest importer and exporter of crude oil, respectively. Crude oil is of strategic value to both countries. This study empirically investigates the volatility spillover effect of international crude oil futures and China-Russia stock market from April $24^{\text {th }}, 2015$ to April $20^{\text {th }}, 2018$, based on the data of international crude oil futures prices, China-Russia stock market composite index, and industry stock index. The empirical results show that there is a short-term relationship between China-Russia stock market composite index and international crude oil futures price. The international crude oil futures price has a greater explanatory power to Russian RTS index, but a smaller explanatory power to Shanghai composite index. All industry stock indices are cointegrated with international crude oil futures prices. Except for China industry and Russia energy, the adjustment coefficient of international crude oil futures price on stock index volatility of other industries is insignificant. This study mainly studies the relationship between international crude oil futures price and the comprehensive stock index and industry stock index of China and Russia, and compares the impact of international crude oil futures price on the stock market of the largest importer and the largest exporter of crude oil to explore the
\end{abstract}




\section{Macrothink}

Asian Journal of Finance \& Accounting ISSN 1946-052X 2019, Vol. 11, No. 1

linkage between crude oil futures price and stock market, and puts forward policy implications based on the empirical results.

Keywords: volatility spillover effect, international crude oil futures, China-Russia stock market, multivariate BEKK-GARCH model, wavelet multiresolution analysis 
1.

\section{Introduction}

Crude oil has always occupied an unshakable position in industry, and its derivatives cover many industries. Due to its poor extraction and refining technology, China imports large quantities of crude oil from abroad, and jumps to the top of the world's crude oil consumption in 2017. China's crude oil dependence is expected to exceed $60 \%$ by 2020 . Thus, the fluctuation of international crude oil prices will have an important impact on China's economy. Russia is currently the world's largest oil reserve country, and the fluctuation of international crude oil prices has a significant impact on its economy. Since the two crude oil crises in the early 1970s and early 1980s, the economic status and financial attributes of crude oil have become increasingly prominent. In order to avoid the risk caused by the fluctuation of crude oil price, the crude oil futures market came into being. The fluctuation of crude oil futures price is inseparable from the corresponding spot price fluctuation. The stock market, which is called the "barometer" of macro-economy, directly reflects the trend of a country's economy. Therefore, the price of crude oil futures reflecting spot price affects the stock market, revealing the economic situation to a certain extent. At present, existing literature on the impact of international crude oil futures prices on composite index and industry index is extremely limited. In view of this, this study investigates the volatility spillover effect of international crude oil futures price and China-Russia composite stock index and industry stock index, and investigates the linkage between crude oil and stock market by comparing the impact of international crude oil futures price on the stock markets of the largest importer and the largest exporter of crude oil.

In previous literature, when discussing the correlation between international crude oil futures and stock market, a single model is often used, but the difference of data is neglected. In this study, according to the characteristics of variable groups in the test, different empirical models are used for analysis. Specifically, this study chooses the international crude oil futures price as the explanatory variable, and the stock market composite index and industry index of China and Russia as the explained variable, and establishes the corresponding variable group. It is found that all the time series are non-stationary, so two schemes are put forward in this study: (1) making first-order difference to the original data, establishing VAR model and GARCH model, then processing the international crude oil futures price with wavelet multiresolution, establishing BEKK-GARCH model, and judging whether there exists volatility spillover effect according to Wald test results; (2) making cointegration test to the original data. On the basis of Granger causality test results, the variable groups are divided and VECM and ECM models are established, respectively. This study explores the relationship between the international crude oil futures and the stock markets of China and Russia through the above-mentioned research methods, and further strengthens the research on the influencing factors of the market, so as to help macroeconomic policymakers better understand the effectiveness of China's financial market and the role of market regulators, and to provide reference for the development of follow-up financial market and formulate more reasonable policies. 


\section{Related Literature}

Most of the existing literature on the linkage between international crude oil futures and stock market is based on stock pricing model. In the stock pricing model, the stock price at each time point corresponds to the discount value of future cash flow. Early theoretical studies have shown that there is a close relationship between crude oil price and macro-economy. Crude oil futures price is the embodiment of crude oil price, and stock market is the barometer of macro-economy. There may be a corresponding relationship between crude oil futures price and stock market. Huang, Masulis and Stoll (1996) proposed that changes in international crude oil futures prices would have an impact on discount rates and future cash flows of companies.

Crude oil price shocks mainly affect inflation and interest rates through influencing the government's monetary policy. When the government is facing the impact of crude oil prices, because crude oil prices affect the production and operation costs of a considerable number of companies, in order to stabilize the economy and investor sentiment, the government usually adjusts the interest rate and inflation rate accordingly. Hooker, Leblanc and Chin (2004) argued that the impact of international crude oil futures prices on inflation is asymmetric. This may be because the government cannot regulate the currency as frequently as the fluctuation of international crude oil futures prices, so the impact of international crude oil futures prices on inflation is band-wise.

In addition, changes in crude oil prices will also have an impact on the nation's macroeconomic situation, industry development and companies' own operating conditions. Fried and Schultze (1975) argue that rising crude oil prices would lead to lower global demand and economic recession. Hamilton (1983) constructed a six-variable system similar to the real macro-economy and found that the rise of international crude oil prices would indeed lead to economic recession. The most obvious industry impacted by the rising crude oil price would be the crude oil extraction and processing industry. In addition, most companies use crude oil more or less as fuel (raw materials), and the fluctuation of crude oil price undoubtedly affect the operating conditions of companies, and then affect the cash flow of companies.

Early studies on the linkage between international crude oil futures prices and stock markets did not find significant results. The multi-factor model used by Chen, Roll and Ross (1986) is a model for early research on the impact of international crude oil futures prices on stock markets. Since then, Hamao (1990), Ferson and Havey (1994) have extended the model, but no significant impact of international crude oil futures prices on the stock market has been found in the US and Japanese stock markets. However, most subsequent studies have come to the conclusion that international crude oil futures prices impact the stock market. Jones and Kaul (1996) found that the impact of international crude oil futures prices on Canadian and American stock markets is significant. Qi and Zhu (2011) and Zhang and Wang (2013) found that the fluctuation of international crude oil futures prices had a strong and lasting influence on the stock markets of the United Kingdom and the United States, but had a small impact on the stock markets of China and India. Zhuge and Hao (2009) found that there was a long-term 
cointegration relationship between the volatility of China's stock market and the volatility of international crude oil futures prices between 2002 and 2008, which was consistent with the results obtained by Zhang (2013) using data from 2006 to 2010. Zhu (2015) established an asymmetric BEKK model and Wald test. It was found that there was a two-way volatility spillover effect between international crude oil futures and stock markets.

Despite a great deal of literature, there are relatively few studies on the impact of international crude oil futures prices on various industry indices of the stock market. Sadorsky (2001) found that the stock returns of oil companies are positively correlated with oil prices, while the stock returns of natural gas companies are negatively correlated with them. Lao (2008) used the method of multivariate equation regression and concluded that the international crude oil futures price has a significant positive impact on the first-class industry index (including financial, industrial and other categories of index). However, by establishing GED-GARCH (1,1)-M model, Jin and Jin (2010) found that international crude oil futures prices had significant negative effects on automobile, construction, finance and other industries, but had significant positive effects on the crude oil industry and the gas industry. Dai (2014) used ARMA-EGARCH-M model to analyze the data from 2009 to 2013 and found that the rise of international crude oil futures prices have a positive impact on the mining industry, but a negative impact on the chemical industry.

Most of the previous literature assumed that there was a stable linear relationship between macro-economy and international crude oil futures prices. It was not until Mork (1989) found that the impact of crude oil price shocks on macro-economy was non-linear and asymmetric that this assumption was overturned. In addition, some previous literature chose the composite index as the explained variable, but did not consider the possible correlation between the industry index and the international crude oil futures price. When studying the impact of the international crude oil futures price on the industrial stock index, most literature utilized a single model to analyze all the data, without considering the differences between the data, and the results are prone to bias. At the same time, many studies only analyze the linkage between international crude oil futures prices and a country's stock market. Therefore, in the empirical research, (1) this study makes first-order difference processing of the original data, establishes VAR model and GARCH model, and then makes wavelet multiresolution processing of the international crude oil futures price, and establishes BEKK-GARCH model; (2) This study not only investigates the stock market composite index of China (the largest crude oil importer) and Russia (the largest crude oil exporter), but also considers the industry index of China and Russia; (3) In the study of the impact of crude oil futures prices on the stock industry index, this study does not use a single model to analyze, but first divides the data into groups of variables with different characteristics, and then uses different models to analyze different groups of variables.

\section{Channels of Crude Oil Influencing Stock Market}

On the one hand, this study focuses on the macroeconomic impact on the stock market, i.e., how the discount rate changes when the crude oil price fluctuates; on the other hand, it focuses on the impact of specific industries on the stock market, i.e., how the future cash flow 
of companies changes when the crude oil price fluctuates.

\subsection{The Impact of Crude Oil Futures Prices on the Stock Market as a Whole}

Crude oil price fluctuation affects the stock market through trading currency. Since the birth of crude oil futures contracts, crude oil derived financial attributes. Demand and supply are no longer the only factors that influence the price of crude oil. Capital injection has gradually made crude oil out of the control of oil-producing countries. At present, international crude oil futures are mainly valued and settled in US dollar, sterling pound, and other currencies. Monetary policies and corresponding exchange rates of various countries affect crude oil trading through interaction.

In addition, the fluctuation of crude oil price also affects the stock market by influencing macro-economy. When the price of crude oil rises, the consumption level of net importing countries tends to decreases, the purchasing power of money decreases, and the inflationary pressure increases. The situation of net exporting countries is the opposite. As the number of net importers of crude oil is greater than that of net exporters of crude oil, when crude oil prices rise, the global economy generally shows a downward trend. At this time, inflationary pressure is high, investors will consider the expected discount rate when calculating stock prices, and naturally think that the future inflation rate will be higher than previously estimated, and then change the discount rate. Because the stock price is lower than the present value, the yield will also be lower. At the same time, crude oil futures and stock market are both high-risk and high-yield financial markets. There may be a competitive relationship between them. When the government increases the funds used to maintain the price stability of crude oil futures, the funds available for investing in the stock market will naturally decrease, and the reduction of funds will lead to the decline of the stock market and the reduction of the yield.

\subsection{Impact of Crude Oil Futures Prices on Related Industries}

Referring to China's classification standards of national economic industries, this study selects five industries closely related to crude oil to analyze the impact of crude oil prices on specific industries.

1) In the mining industry, the price of crude oil has risen, which is good news for crude oil and coal miners, but bad news for other resource miners. Therefore, the impact of crude oil on the extraction industry depends on the tripartite game between crude oil, coal and other resources;

2) In the manufacturing industry, crude oil is used as raw material or fuel, and the rise of crude oil price will have a negative effect;

3) In the electricity, heat, gas and water production and supply industry, rise of crude oil price leads to increase in supply cost and decrease in corporate profits;

4) In the construction industry, asphalt and other raw materials in engineering consumes a large amount of industrial lubricant. Industrial lubricant is extracted from crude oil, so if the price of crude oil rises then the future cash flow of companies will decrease. 
5) The transportation, storage, and postal industry is more sensitive to crude oil prices than most industries, such as road, rail, and air transport. Crude oil is a direct or indirect fuel, and the rising price of crude oil will lead to an increase in operating costs, thus reducing the overall profit of the transport industry.

\section{Empirical Analysis}

This study focuses on the linkage between international crude oil futures price and China-Russia stock market, specifically the impact of international crude oil futures price on the composite stock index of the stock market and the industry stock index. This study chooses the daily frequency data from April $24^{\text {th }}, 2015$ to April $20^{\text {th }}, 2018$. Specific variables are:

1) International crude oil futures price: The crude oil futures of China and Russia are linked to Brent crude oil futures price, which is one of the three major international crude oil futures prices. Therefore, they are regarded as international crude oil futures price. The data are gathered from Wind database.

2) Composite stock index: Shanghai Stock Index (SHA) and Russia RTS Index (RTS) are selected as the stock market indices of China and Russia, respectively. The data are collected from Bloomberg database.

3) Industry Stock Index: For China's stock market, referring to the industry division standard of the National Bureau of Statistics, in the industry index of the China Stock Index Limited Company, co-founded by Shanghai Stock Exchange and Shenzhen Stock Exchange, this study selects ZCP, ZZFZ, ZZGY, ZZJZ, ZZJT, ZNY, ZZNY, ZFZ, and ZRL data from Wind database; for the Russian stock market, this study selects the industry index corresponding to the Chinese stock market, respectively, i.e., Russia car parts (RCP), Russia textile (RFZ), Russia industry (RGY), Russia construction (RJZ), Russia transportation (RYS), Russia energy (RNY), Russia fuel (RRL). The data are gathered from Bloomberg database.

Jarque-Bera tests on the 17 variables show that all the variables exhibit the characteristics of "sharp peak and thick tail", which does not comply with the normal distribution and has a wide range of fluctuations. Stationarity tests find that the 17 variables have unit roots at the $1 \%$ significance level, i.e., they are non-stationary time series. In view of this, this study proposes two schemes for further research: 1. First-order difference of the original data; 2. cointegration test of the original data.

\subsection{First-Order Difference}

After making first-order difference for the original data, the 17 variables selected reject the null hypothesis that there is a unit root at the $1 \%$ significance level, i.e., all variables become stationary series. The results of Granger causality test show that there is a two-way Granger causality between Brent crude oil futures price and Russia industry; Brent crude oil futures price is the Granger cause of ZZNY, ZZRL, RCP, and RNY; Brent crude oil futures price is also the Granger cause of Russia textile (RFZ) and Russia fuel (RRL). There is no Granger 
causality between Brent crude oil futures price and the other nine variables.

For Brent crude oil futures price with two-way Granger causality and RTS index, VAR regression is used to judge the relationship between them. AIC, FPE and HQ information criteria show that the optimal lag period of VAR model is two lags. The results of VAR regression are shown in Table 1.

Table 1.VAR Results

\begin{tabular}{|c|c|c|c|}
\hline & DBrent & DRTS & DRGY \\
\hline \multirow{3}{*}{ DBrent(-1) } & -0.037323 & -0.055881 & 0.039866 \\
\hline & $(0.04548)$ & $(0.69359)$ & $(0.06696)$ \\
\hline & {$[0.82060]$} & {$[-0.08057]$} & [0.59539] \\
\hline \multirow{3}{*}{ DBrent(-2) } & -0.000506 & -0.275300 & -0.183224 \\
\hline & $(0.04554)$ & $(0.69449)$ & $(0.06705)$ \\
\hline & {$[-0.01111]$} & {$[-0.39640]$} & {$[-2.73283]$} \\
\hline \multirow{3}{*}{ DRTS $(-1)$} & -0.002704 & -0.015363 & -0.001126 \\
\hline & $(0.00319)$ & $(0.04864)$ & $(0.00470)$ \\
\hline & {$[-0.84773]$} & {$[-3.31588]$} & {$[-0.23989]$} \\
\hline \multirow{3}{*}{ DRTS (-2) } & -0.002807 & -0.012482 & -0.005343 \\
\hline & $(0.00318)$ & $(0.04853)$ & $(0.00468)$ \\
\hline & {$[-0.88212]$} & {$[-2.25721]$} & [1.14055] \\
\hline \multirow{3}{*}{$\operatorname{DRGY}(-1)$} & 0.089737 & 2.145214 & 0.219919 \\
\hline & $(0.02975)$ & $(0.45373)$ & $(0.04380)$ \\
\hline & {$[3.01601]$} & [4.72793] & {$[5.02068]$} \\
\hline \multirow{3}{*}{ DRGY(-2) } & -0.026533 & -0.948154 & -0.086517 \\
\hline & $(0.03018)$ & $(0.46021)$ & $(0.04443)$ \\
\hline & {$[-0.87920]$} & {$[-2.06026]$} & {$[-1.94736]$} \\
\hline \multirow{2}{*}{$\mathrm{C}$} & 0.029198 & 0.284026 & 0.074043 \\
\hline & $(0.03792)$ & $(0.57822)$ & $(0.05582)$ \\
\hline
\end{tabular}


[0.77006]

$\mathrm{R}^{2}$

VAR test results show that: 1 . The first and second lag orders of Brent crude oil futures price have significant negative effects on itself; 2 . The first and second lag orders of RTS index have negative effects on itself, among which the first lag order has greater and more significant effects; 3 . The first lag order of Russia industry has positive effects on itself, while the second lag order has negative effects on itself. The influence of the second lag order is greater and more significant; 4 . The influence of the first and second lag order of RTS index on Brent crude oil futures price is equal, while the coefficient of the second lag order is more significant; 5. The first and second lag order of Russia industry has greater influence on RTS index, and the effect is opposite.

Before impulse response, this study first detects the stability of VAR by AR root graph. The stability test diagram and impulse response diagram are shown in Figure 1.

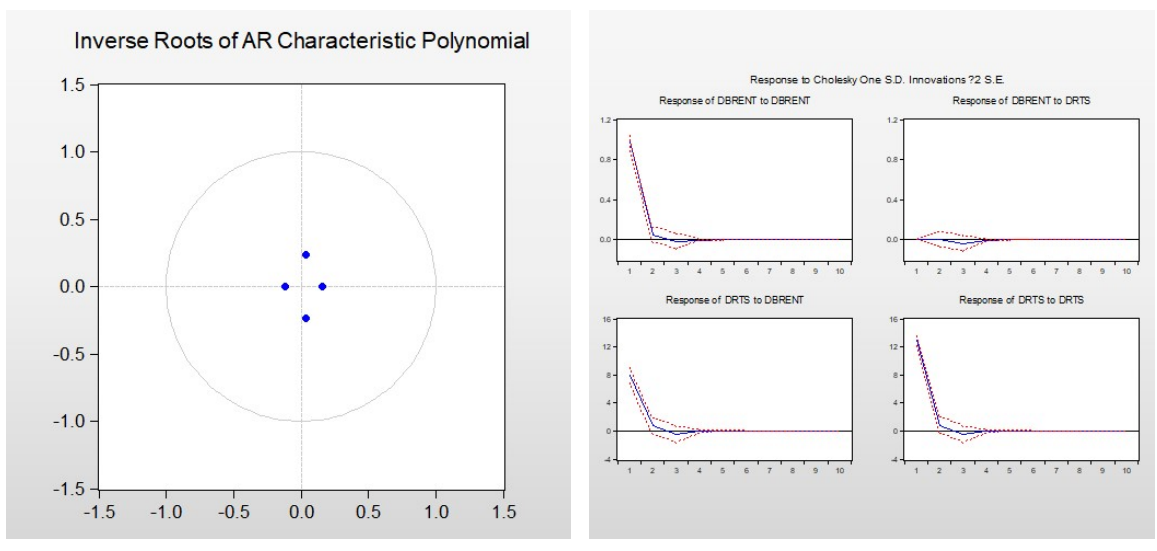

Figure 1. AR root graph and impulse response graph

The impulse response results show that the impact of RTS index on Brent crude oil futures price has two lags; the impact of Brent crude oil futures price on RTS index has no lag, and has immediate impact and lasts about four periods; in the long run, both RTS index and Brent crude oil futures price are stable, and the impact effect is basically unchanged.

Based on the established VAR model, the variance decomposition of RTS index and crude oil futures price is carried out. Before variance decomposition, Cholesky orthogonalization is used to eliminate the serial correlation and autocorrelation among residuals. The results of variance decomposition are shown in Table 2. 
Table 2.Variance Decomposition Results

\begin{tabular}{|c|c|c|c|c|c|c|c|}
\hline \multicolumn{4}{|c|}{ DBrent } & \multicolumn{4}{|c|}{ DRTS } \\
\hline Period & S.E. & DBrent & DRTS & Period & S.E. & DBrent & DRTS \\
\hline 1 & 0.984979 & 100.0000 & 0.000000 & 1 & 15.16729 & 27.71142 & 72.28858 \\
\hline 2 & 0.986134 & 99.99845 & 0.001547 & 2 & 15.20552 & 27.79667 & 72.20333 \\
\hline 3 & 0.987249 & 99.81215 & 0.187845 & 3 & 15.22351 & 27.85850 & 72.14150 \\
\hline 4 & 0.987266 & 99.80984 & 0.190164 & 4 & 15.22392 & 27.85987 & 72.14013 \\
\hline 5 & 0.987268 & 99.80968 & 0.190320 & 5 & 15.22396 & 27.85994 & 72.14006 \\
\hline 6 & 0.987268 & 99.80967 & 0.190329 & 6 & 15.22397 & 27.85994 & 72.14006 \\
\hline 7 & 0.987268 & 99.80967 & 0.190329 & 7 & 15.22397 & 27.85994 & 72.14006 \\
\hline 8 & 0.987268 & 99.80967 & 0.190329 & 8 & 15.22397 & 27.85994 & 72.14006 \\
\hline 9 & 0.987268 & 99.80967 & 0.190329 & 9 & 15.22397 & 27.85994 & 72.14006 \\
\hline 10 & 0.987268 & 99.80967 & 0.190329 & 10 & 15.22397 & 27.85994 & 72.14006 \\
\hline
\end{tabular}

The results of variance decomposition show that the initial RTS index has a low explanatory power to Brent crude oil futures price fluctuation, but it increases slowly with the increase of futures, and remains unchanged from the fourth to $0.19 \%$. To be specific, the influence of RTS index on Brent crude oil futures price fluctuation has a lagging effect, and the explanatory power is low. Brent crude oil futures price has a strong explanation for itself. The contribution of Brent crude oil futures price to RTS index is medium. The first explanation is $27.71 \%$, but the growth is very slow. By the fifth period, Brent crude oil futures price stagnates to $27.86 \%$. Therefore, Brent crude oil futures price has no lagging effect on RTS index, and its impact is instantaneous. At the same time, it also shows that Brent crude oil futures price has stronger self-development and strengthening ability. The results of variance decomposition are consistent with those of impulse response.

In this study, Breusch-Godfrey Serial Correlation LM Test is used to test serial correlation. The results show that serial correlation exists in the variable groups DSHA \& DBrent, DZZCP \& DBrent, DZZFZ \& DBrent, DZJZ \& DBrent, and DZZJT \& DBrent. In order to eliminate serial correlation, the ARMA model is introduced. The results are shown in Table 3. 


\section{Macrothink}

At this time, serial correlation of each equation has been eliminated.

Table 3. Serial Correlation Test Results

\begin{tabular}{lccc}
\hline Variable Group & Serial Correlation Elimination Method & t-value & p-value \\
\hline DSHA \& DBrent & $\operatorname{ar}(1), \operatorname{ar}(2), \operatorname{ma}(1)$ & 1.474066 & 0.2292 \\
DZZCP \& DBrent & $\operatorname{ar}(1), \operatorname{ar}(2), \operatorname{ma}(1), \operatorname{ma}(2)$ & 1.195445 & 0.3028 \\
DZZFZ \& DBrent & $\operatorname{ar}(2), \operatorname{ar}(3)$ & 3.636489 & 0.2650 \\
DZZJZ \& DBrent & $\operatorname{ar}(1)$ & 4.018771 & 0.1811 \\
& $\operatorname{ar}(1), \operatorname{ar}(3), \operatorname{ma}(1), \operatorname{ma}(3)$ & 3.215683 & 0.4032
\end{tabular}

In view of the fact that the regression equation constructed in this study contains only one explanatory variable, this study tests the $\mathrm{ARCH}$ effect of the regression equation. The results show that the ARCH effect exists in all variables except the futures prices of China textile and Brent Crude Oil. For the group of variables without ARCH effect, i.e., the futures prices of China textile and Brent crude oil, OLS regression is performed directly. Wald test shows that there is no significant relationship between them. For the variables with ARCH effect, GARCH model is used to further analyze: if they do not show serial correlation in LM test, the first-order autoregression of the explained variables is added to the equation. The re-test results of ARCH effect show that after the establishment of GARCH model, the ARCH effect of each variable group has been eliminated.

In order to further study the volatility spillover effect between Brent crude oil futures price and stock index of China and Russia, this study chooses BEKK-GARCH model, which is expressed as follows:

$$
\begin{gathered}
\mathrm{Y}_{\mathrm{t}}=\emptyset_{0}+\emptyset_{1} \mathrm{Y}_{\mathrm{t}-1}+\cdots+\emptyset_{\mathrm{p}} \mathrm{Y}_{\mathrm{t}-\mathrm{p}}+\varphi_{0} \mathrm{X}_{\mathrm{t}}+\varepsilon_{\mathrm{t}}, \mathrm{p}>0 \\
\mathrm{H}_{\mathrm{t}}=\mathrm{CC}^{\prime}+\mathrm{B}^{\prime} \mathrm{H}_{\mathrm{t}-1} \mathrm{~B}+\mathrm{A}^{\prime} \varepsilon_{\mathrm{t}-1} \varepsilon_{\mathrm{t}-1}{ }^{\prime} \mathrm{A}
\end{gathered}
$$

in which $Y_{t}$ is the stock price index, $X_{t}$ is the crude oil futures price, $H_{t}=\left[\begin{array}{l}h_{11, t} h_{12, t} \\ h_{21, t} h_{22, t}\end{array}\right]$ is the conditional covariance matrix, $\mathrm{A}$ and $\mathrm{B}$ are the parameter matrices of order $2 * 2$, A reflects the ARCH effect of volatility, B reflects the GARCH effect of volatility, and $\mathrm{C}$ is the upper triangular matrix of order $2 * 2$.

The conditional covariance matrix can be expanded as follows: 


$$
\begin{gathered}
\mathrm{h}_{11, \mathrm{t}}=\mathrm{C}_{11}^{2}+\beta_{11}^{2} \mathrm{~h}_{11, \mathrm{t}-1}+2 \beta_{11} \beta_{21} \mathrm{~h}_{12, \mathrm{t}-1}+\beta_{21}^{2} \mathrm{~h}_{22, \mathrm{t}-1}+\alpha_{11} \alpha_{21} \varepsilon_{1, \mathrm{t}-1} \varepsilon_{2, \mathrm{t}-1} \\
+\alpha_{21}^{2} \varepsilon_{2, \mathrm{t}-1}^{2}+2 \alpha_{11} \alpha_{21} \mathrm{~h}_{12, \mathrm{t}-1} \\
\mathrm{~h}_{22, \mathrm{t}}=\mathrm{C}_{21}^{2}+\mathrm{C}_{22}^{2}+\beta_{12}^{2} \mathrm{~h}_{11, \mathrm{t}-1}+2 \beta_{12} \beta_{22} \mathrm{~h}_{12, \mathrm{t}-1}+\beta_{22}^{2} \mathrm{~h}_{22, \mathrm{t}-1}+\alpha_{12}^{2} \varepsilon_{1, \mathrm{t}-1}^{2} \\
+2 \alpha_{11} \alpha_{22} \varepsilon_{1, \mathrm{t}-1} \varepsilon_{2, \mathrm{t}-1}+\alpha_{22}^{2} \varepsilon_{2, \mathrm{t}-1}^{2} \\
\mathrm{~h}_{12, \mathrm{t}}=\mathrm{C}_{11} \mathrm{C}_{21}+\beta_{11} \beta_{12} \mathrm{~h}_{11, \mathrm{t}-1}+\left(\beta_{12} \beta_{21}+\beta_{11} \beta_{12}\right) \mathrm{h}_{12, \mathrm{t}-1}+\beta_{21} \beta_{22} \mathrm{~h}_{22, \mathrm{t}-1} \\
+\alpha_{11} \alpha_{21} \varepsilon_{1, \mathrm{t}-1}^{2}+\left(\alpha_{12} \alpha_{21}+\alpha_{11} \alpha_{22}\right) \varepsilon_{1, \mathrm{t}-1} \varepsilon_{2, \mathrm{t}-1}+\alpha_{21} \alpha_{22} \varepsilon_{2, \mathrm{t}-1}^{2}
\end{gathered}
$$

in which $h_{11, t}$ denotes the conditional variance of stock price index at time $\mathrm{t}, h_{22, t}$ denotes

\begin{tabular}{|c|c|c|c|}
\hline $\begin{array}{l}\text { Explained } \\
\text { Variable }\end{array}$ & $\begin{array}{l}\text { Insignificant Coefficients in } \\
\text { the Model }\end{array}$ & $\begin{array}{l}\mathrm{A}(1,2) \text { and } \\
\mathrm{B}(1,2)\end{array}$ & $\begin{array}{c}\text { Comparison of } \mathrm{B}(1,1) \\
\text { with } \mathrm{B}(2,2)\end{array}$ \\
\hline DSHA & $\mathrm{M}(1,2)$ & $\begin{array}{c}\text { Both } \\
\text { Significant }\end{array}$ & $>$ \\
\hline DRTS & $\mathrm{M}(1,2)$ & $\begin{array}{c}\text { Both } \\
\text { Significant }\end{array}$ & $<$ \\
\hline DZZCP & $\mathrm{M}(1,2)$ & $\begin{array}{c}\text { Both } \\
\text { Significant }\end{array}$ & $>$ \\
\hline DZZGY & Null & $\begin{array}{c}\text { Both } \\
\text { Significant }\end{array}$ & $<$ \\
\hline DZZJT & $\mathrm{M}(1,2)$ & $\begin{array}{c}\text { Both } \\
\text { Significant }\end{array}$ & $<$ \\
\hline
\end{tabular}
the conditional variance of crude oil futures price at time $t$, and $h_{12, t}$ denotes the conditional covariance of stock price index and crude oil futures price.

The BEKK-GARCH model is used for the above variable groups. Some parameters of the model are selected as Table 4 .

Table 4. Test Results of BEKK-GARCH Model 
DZZJZ

DZZNY

DZZRL

DRCP

DRFZ

DRJZ

DRNY

DRRL

DRYS
$\mathrm{M}(1,2)$

$\mathrm{M}(1,2)$

$\mathrm{M}(1,2)$

$\mathrm{M}(1,2)$

$\mathrm{M}(1,2)$

$\mathrm{M}(1,2)$

$\mathrm{M}(1,2)$

$\mathrm{M}(1,2)$

$\mathrm{M}(1,2)$
Both

Significant

Both

Significant

Both

Significant

Both

Significant

Both

Significant

Both

Significant

Both

Significant

Both

Significant

Both

Significant

Table 4 shows that in the BEEK-GARCH model, except for the $M(1,2)$ coefficients of the futures prices of China industry and Brent crude oil, the other coefficients are significant, which confirms the applicability of the model. The coefficients of $\mathrm{A}(1,2)$ and $\mathrm{B}(1,2)$ are significant, which indicates that the price of Brent crude oil futures has volatility spillover effect with China, Russian composite stock index, and industry stock index. Comparing B(1,1) with $\mathrm{B}(2,2)$, it can be found that in the combination of Shanghai Stock Index, China auto parts, Russia textile, Russia construction, and Brent crude oil futures prices, $B(1)>B(2,2)$, which indicates that the stock index reacts to shocks faster and has shorter cycle than Brent crude oil futures prices. In other portfolios, $\mathrm{B}(1,1)<\mathrm{B}(2,2)$, indicating that the volatility of stock index is greater than that of Brent crude oil futures price, and the response period to information shocks is longer.

Wavelet transformation and multiresolution processing can transform the time and frequency of time series, and study the morphology of a subspace sequence satisfying multiresolution conditions in different subspaces. In this study, discrete wavelet transform (DWT) is used to stratify and process the original data, and dyadic orthogonal wavelet multiresolution analysis 


\section{Macrothink}

Asian Journal of Finance \& Accounting

ISSN 1946-052X 2019, Vol. 11, No. 1

method is used to decompose the original data into short, medium and long-term data. Among them, the time scale of short-term data (high frequency signal) is $2^{1}=2$ days and $2^{2}=4$ days (close to work week), the medium-term time scale is $2^{3}=8$ days and $2^{4}=16$ days (week to month), and the long-term time scale is $2^{5}=32$ days (month).

The Granger causality tests of Brent crude oil futures price in short, medium and long periods, original data, composite index of China and Russia stock markets and industry index show that only RTS index and Brent crude oil futures price, RTS index and Brent crude oil futures price in short term, and SHA index and Brent crude oil futures price have two-way Granger causality. The regression results of BEEK-GARCH model are shown in Figure 2, Figure 3, and Figure 4.

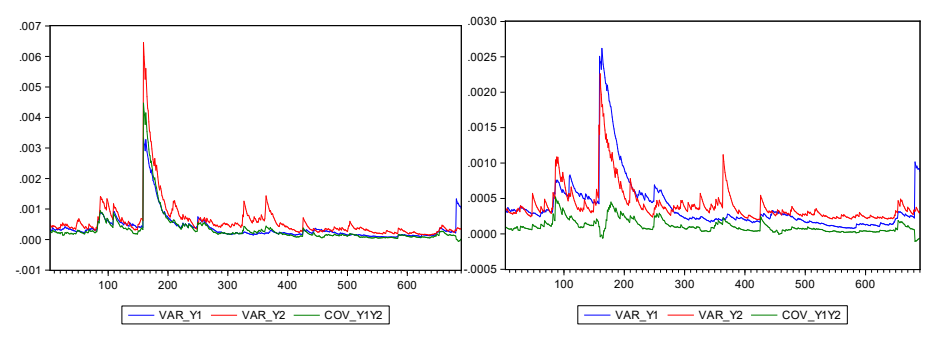

Figure 2. RTS and BRENT Figure 3 RTS and BRENT Short

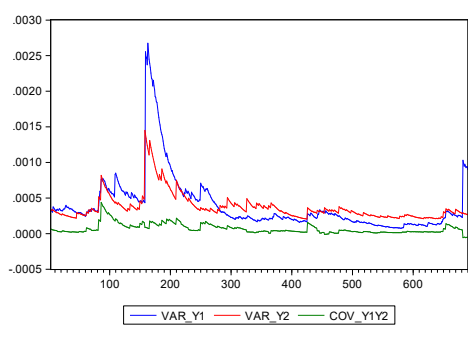

Figure 4. SHA and BRENT

Wald test is conducted on RTS index and Brent crude oil futures price, and SHA index and Brent crude oil futures price, to determine the direction of volatility spillover effect. The results are shown in Table 5. 
Table 5. Wald Test Results

\begin{tabular}{|c|c|c|c|c|c|c|}
\hline \multirow[t]{3}{*}{$H_{0}$} & \multirow{2}{*}{\multicolumn{2}{|c|}{$\begin{array}{l}\text { There is no two-way } \\
\text { volatility spillover effect } \\
\text { between Brent crude oil } \\
\text { futures price and RTS } \\
\text { index } \\
H_{0}: \alpha_{12}=\alpha_{21}=\beta_{12}=\beta_{2} \text { : }\end{array}$}} & \multirow{2}{*}{\multicolumn{2}{|c|}{$\begin{array}{c}\text { There is no one-way } \\
\text { volatility spillover effect } \\
\text { between RTS index and } \\
\text { Brent crude oil futures } \\
\text { price } \\
H_{0}: \alpha_{12}=\beta_{12}=0\end{array}$}} & \multirow{2}{*}{\multicolumn{2}{|c|}{$\begin{array}{l}\text { There is no one-way } \\
\text { volatility spillover effect } \\
\text { between Brent crude oil } \\
\text { futures price and RTS } \\
\text { index } \\
H_{0}: \alpha_{21}=\beta_{21}=0\end{array}$}} \\
\hline & & & & & & \\
\hline & F-value & $\mathrm{p}$-value & F-value & p-value & F-value & $p$-value \\
\hline $\mathrm{S}$ & 749.0268 & 0.0000 & 282146.2 & 0.000 & 941138.14 & 0.0000 \\
\hline$d_{1}$ & 2526.654 & 0.0000 & 1761374 & 0.0000 & 34865.67 & 0.0000 \\
\hline$d_{2}$ & 7973.026 & 0.0000 & 1848848 & 0.0000 & 296475.1 & 0.0000 \\
\hline$d_{3}$ & 0.2450 & 0.9128 & 0.3120 & 0.7319 & $7.42 \mathrm{e}-009$ & 0.9999 \\
\hline \multirow[t]{3}{*}{$H_{0}$} & \multirow{2}{*}{\multicolumn{2}{|c|}{$\begin{array}{c}\text { There is no two-way } \\
\text { volatility spillover effect } \\
\text { between Brent crude oil } \\
\text { futures price and } \\
\text { Shanghai Composite } \\
\text { Index } \\
H_{0}: \alpha_{12}=\alpha_{21}=\beta_{12}=\beta_{2} \text { : }\end{array}$}} & \multicolumn{2}{|c|}{$\begin{array}{c}\text { There is no one-way } \\
\text { volatility spillover effect } \\
\text { between Shanghai } \\
\text { Composite Index and } \\
\text { Brent crude oil futures } \\
\text { price }\end{array}$} & \multicolumn{2}{|c|}{$\begin{array}{l}\text { There is no one-way } \\
\text { volatility spillover effect } \\
\text { between Brent crude oil } \\
\text { futures price and } \\
\text { Shanghai Composite } \\
\text { Index }\end{array}$} \\
\hline & & & \multicolumn{2}{|c|}{$H_{0}: \alpha_{12}=\beta_{12}=0$} & \multicolumn{2}{|c|}{$H_{0}: \alpha_{21}=\beta_{21}=0$} \\
\hline & F-value & p-value & F-value & p-value & F-value & p-value \\
\hline $\mathrm{S}$ & 6551.491 & 0.0000 & 401.2298 & 0.000 & 973683.0 & 0.0000 \\
\hline$d_{1}$ & 1.026588 & 0.3268 & 2.568956 & 0.4456 & 1.50792 & $\begin{array}{c}0.556 \\
6\end{array}$ \\
\hline
\end{tabular}



$d_{2}$
0.8561
0.5029
0.6122
0.6250
0.2567
0.773
$d_{3}$
0.2380
0.9356
0.4569
0.7259
8.602e-011
0.9999

The results show that there is a two-way volatility spillover effect between the original sequence of Brent crude oil futures price and the data at $d_{1}$ and $d_{2}$ levels and RTS index, while there is no two-way volatility spillover effect between the other levels of Brent crude oil futures price and RTS index; only the original series of Brent crude oil futures price and Shanghai composite index have two-way volatility spillover effect.

The conditional covariance diagram of Brent crude oil futures price and RTS index (Figure 2) shows that the trend of covariance curve is very similar to that of Brent crude oil futures price and RTS index, indicating that the volatility spillover effect between them is very strong, especially in the short term when the volatility spillover effect is more obvious; the volatility spillover effect of Brent crude oil futures price and Shanghai composite index is not very obvious. Although there is a certain relationship between them, the volatility spillover effect of Brent crude oil futures price on Shanghai Composite Index is less than that on RTS Index. The correlation coefficient between Brent crude oil futures price and RTS index and Shanghai Composite Index is basically positive, suggesting that the fluctuation of international crude oil futures price may increase the fluctuation of China and Russia stock market.

\subsection{Cointegration}

In order to prevent the loss of long-term relationship between data caused by first-order difference, this study uses cointegration method to explore whether there is a long-term relationship between variables. This study uses E-G two-step method for cointegration test and regression. The results show that the coefficients of Shanghai Stock Index, China textile, and Brent crude oil futures prices are significant and positive, except that the coefficients between Shanghai Stock Index and Brent crude oil futures prices are not significant. It can be seen that in the long run, the stock index has a positive correlation with the international crude oil futures prices.

The Granger causality test on the long-term cointegration variable group shows that there is a Granger two-way causality between RTS index, Shanghai composite index, and Brent crude oil futures price, while Brent crude oil futures price is the Granger cause of energy and fuel in China Stock Exchange, the textile industry in China Stock Exchange, Russia industry, Russia construction, Russia energy and Russia transportation are the Granger cause of the origin Brent crude oil futures prices.

The VECM models of Brent crude oil futures price and RTS index, Brent crude oil futures price and Shanghai composite index, are established, respectively. The impulse response (Figure 5) and variance decomposition results show that the international crude oil futures 
price has considerable explanatory power to the volatility of RTS index and most industry indices, but less explanatory power to the volatility of Shanghai composite index. The volatility of China industry, China transportation, and China textile can be explained by crude oil futures price, but the volatility of China vehicle parts and China transportation can be explained by crude oil futures price more strongly, which indicates that crude oil futures price has a strong impact on the vehicle parts industry and the transportation industry. On the contrary, the composite index of China's stock market and the industry index have less explanatory power to the fluctuation of international crude oil futures price.

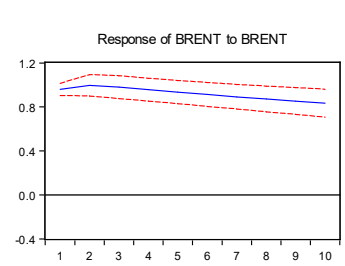

Response of RTS to BRENT

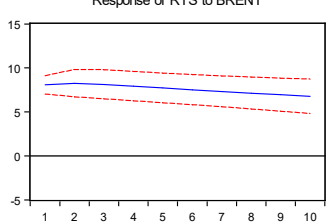

Response of SHANGHAI to BRENT

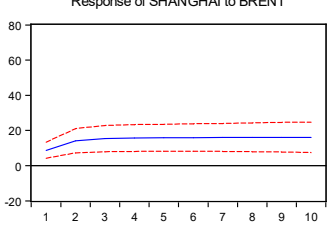

Response of SPEURONY to BRENT

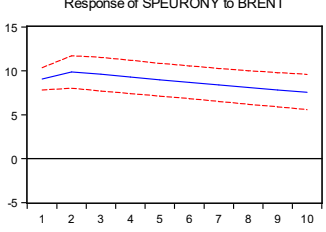

Response to Cholesky One S.D. Innovations ?2 S.E.

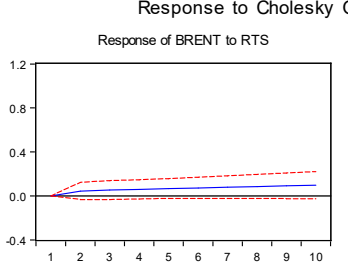

Response of RTS to RTS

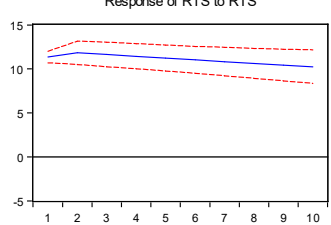

Response of SHANGHAI to RTS

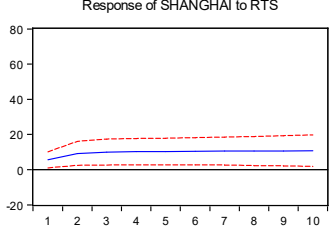

Response of SPEURONY to RTS

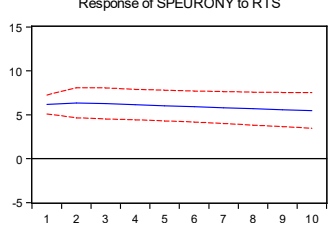

Response of BRENT to SHANGHAI

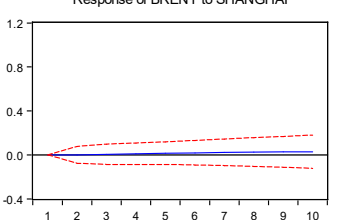

Response of RTS to SHANGHAl

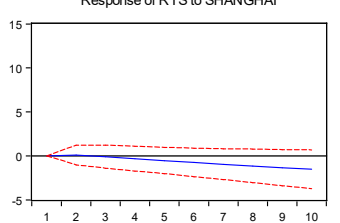

Response of SHANGHAI to SHANGHA

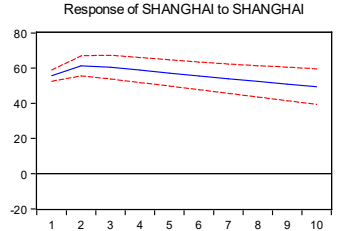

Response of SPEURONY to SHANGHAI

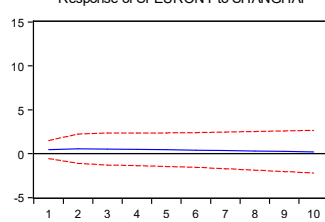

Response of BRENT to SPEURONY

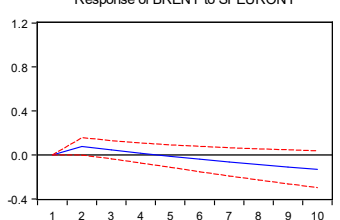

Response of RTS to SPEURONY

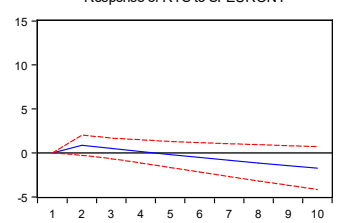

RepOSTe of SHANGHAI TOSPEURONY

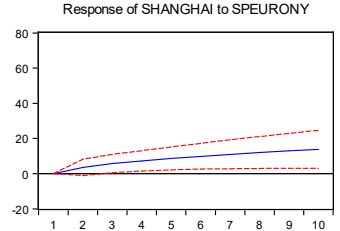

Response of SPEURONY to SPEURONY

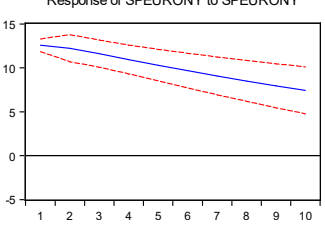

Figure 5. Impulse Response Graph

After checking the long-term relationship among variables, in order to study the adjustment speed of variables when they deviate from the long-term trend, this study constructs an error correction model (ECM) through the first-order linear autoregressive distribution lag model. An ECM model based on cointegration theory is established for the variables without Granger's two-way causality by E-G two-step method. In the ECM model, all error correction coefficients are negative, indicating that the stock market has the function of reverse correction. The results of each variable group are similar, and the absolute values of error correction coefficients are small, which means that if the current fluctuation deviates from the long-term equilibrium, the reverse adjustment of error correction term is limited, i.e., the adjustment range of the error of crude oil futures price to the current explained variable fluctuation is small, and the influence is small. The results of parameter test show that the adjustment coefficients of crude oil futures price to other industry index fluctuations are not significant except China industry and Russia energy, which indicates that there is a long-term 
correlation between China industry and Russia energy industry and international crude oil futures price.

\section{Conclusions and Policy Implications}

Based on the data from April 24 $4^{\text {th }}, 2015$ to April 20 th, 2018 , according to the characteristics of the data in the preliminary test, this study chooses different models to investigate the volatility spillover effect between international crude oil futures and China-Russia stock markets, and explores the relationship between crude oil and stock markets by comparing the impact of international crude oil futures prices on China-Russia stock markets. The results show that Russia composite stock index is more affected by international crude oil futures prices, and the effectiveness of Russian stock market is more obvious. RTS index and Shanghai Stock Exchange index are cointegrated with international crude oil futures prices. The results of variance decomposition show that the volatility of international crude oil futures price has greater explanatory power to the volatility of RTS index. Empirical results show that the composite index and industry index of Chinese stock market are less sensitive to information, reaction speed, and digestion cycle than Russian stock market. In the short run, the rise of international crude oil futures prices will aggravate the volatility of Shanghai Stock Index, China Industrial Index and Russia Energy Index, but the impact on other crude oil-related industries in China and Russia is not obvious; in the long run, all indices are cointegrated with international crude oil futures prices. Therefore, stabilizing international crude oil futures prices has a positive effect on stabilizing stock prices.

Based on the above conclusions, this study puts forward the following policy implications: since most of the factors affecting crude oil supply and demand are not controlled, the government needs to improve the financial supervision system to effectively control malicious speculation or malicious long (short) speculation, so as to stabilize the international crude oil price at an appropriate level. In addition, because Chinese stock market is a weak efficient market (or even near an ineffective market), information is controlled by a few people, most ordinary investors find it difficult to obtain effective information through normal channels, and it is common that a large amount of funds manipulate the stock price. Therefore, the relevant regulatory bodies of China's stock market should strengthen the monitoring of the flow of large amounts of funds, eliminate malicious manipulation of stock prices, reduce the occurrence of insider trading, and enhance the effectiveness of China's stock market.

\section{References}

Chen, N. F., Roll, R., \& Ross, S. A. (1986). Economic Forces and the Stock Market. Journal of Business, 59(3), 383-403. https://doi.org/10.1086/296344

Dai, D. (2014). The Impact of International Crude Oil Futures Price Change on China's Industrial Stock Index Return. Inner Mongolia University.

Ferson, W. E., \& Harvey, C. H. (1994). Sources of Risk and Expected Returns in Global Equity Markets. Journal of Banking and Finance, 18(4), 775-803. https://doi.org/10.1016/0378-4266(93)00020-P 
Fried, E.R., \& Schultze, C. L. (1975). Higher Oil Prices and the World Economy: The Adjustment Problem. The Brookings Institution Press. p.105.

Hamao, Y., Masulis, R. W., \& Ng, V. (1990). Correlations in Price Changes and Volatility across International Stock Markets. Review of Financial Studies, 3(2), 281-307. https://doi.org/10.1093/rfs/3.2.281

Hamilton, J. D. (1983). Oil and the Macroeconomy Since World War II. Journal of Political Economy, 91(2), 228-248. https://doi.org/10.1086/261140

Huang, R. D., Masulis, R. W., \& Stoll, H. R. (1996). Energy Shocks and Financial Markets. $\begin{array}{lllll}\text { Journal of } & \text { Futures } & \text { Markets, } & 16(1), & 1-27 .\end{array}$ https://doi.org/10.1002/(SICI)1096-9934(199602)16:1<1::AID-FUT1>3.0.CO;2-Q

Jin, H., \& Jin, Q. (2010) The Impact of International Oil Price on China's Stock Market: Empirical Analysis Based on Industry Data (in Chinese). Financial Research, 2010(2), 173-187.

Jones, C. M., \& Kaul, G. (1996). Oil and the Stock Markets. Journal of Finance, 51(2), 463-491. https://doi.org/10.1111/j.1540-6261.1996.tb02691.x

Lao, J. (2008). Does Oil Price Have an Impact on the Shanghai Composite Index? - An Empirical Analysis Based on Data from 2000 to 2007 (in Chinese). World Economic Situation, 2008(5), 71-76.

Leblanc, M., \& Chinn, M. D. (2004). Do High Oil Prices Presage Inflation? The Evidence From G-5 Countries. Santa Cruz Center for International Economics Working Paper, 39(2), 38-48. https://doi.org/10.2139/ssrn.509262

Mork, K. A. (1989). Oil and the Macroeconomy When Prices Go Up and Down: An Extension of Hamilton's Results. Journal of Political Economics, 97(3), 740-744. https://doi.org/10.1086/261625

Qi, Q., \& Zhu, H. (2011). Econometrics Study of Relationship between International Oil Market and Stock Markets of China and USA (in Chinese). Financial Theory and Practice, 2011(7), 82-87.

Sadorsky, P. (2001). Risk Factors in Stock Returns of Canadian Oil and Gas Companies. Energy Economics, 23(1), 17-28. https://doi.org/10.1016/S0140-9883(00)00072-4

Zhang, H. (2013). A Comparative Study of the Impact of Crude Oil Price Fluctuations on Stock Prices: Perspective of Different Industries and Periods (in Chinese). Zhejiang University of Technology.

Zhang, X., \& Wang, J. (2013). International Comparison of the Impact of Crude Oil Price on Stock Market (in Chinese). Price Theory and Practice, 2013(1), 75-76.

Zhu, C. (2015). Spillover Effects among Spot Market, Exchange Rate Market, and Stock Market with Crude Oil Futures(in Chinese). Ocean University of China. 
Zhuge, S., \& Hao, X. (2009). Oil Price Shocks at Home and Abroad and Chinese Stock Market (in Chinese). China Price, 2009(6), 41-44. 